Serebriakova V. V., PhD in Philology, Senior Lecturer at the Department of "Philology", State Institution "Odessa National Maritime University"

\title{
THE PECULIARITIES OF RENDERING ENGLISH COLOUR NAMES IN UKRAINIAN TRANSLATION
}

\begin{abstract}
Summary. The article has been devoted to the description of colour names in the aspect of their functioning in belleslettres style and their adequate rendering in artisic translation from English into Ukrainian. Nominations of colour have been investigated as linguistic units with semantic sustainability, high adaptiveness, and variability depending on the author's cultural background and experience. Colour names have been studied as linguistic and cultural symbols, charged by certain mentality and expressiveness. The topic of the research is up-to-date in the paradigm of the functional-communicative approach to translation. In the focus of the research there are various types of colour names and the peculiarities of rendering English colour names in Ukrainian translation. The research is done on the basis of the long short stories Dandelion Wine' by Ray Bradbury and 'The Great Gatsby' by Francis Scott Fitzerald. The colour names' semantics is realized in belleslettres texts on linguistic, extralinguistic and cultural levels. It has been proved that colour names often have symbolic meaning in artistic texts. Being associated with the author's mentality and world outlook, symbols are relevant for artistic translation in general. Thus, it has been resumed that adequate rendering of colour names is essential for faithful translation. To preserve stylistic specificity of the source text, in particular in the aspect of redering the semantics of colour names, translators employ proper translation operations according to the chosen translation strategy of the communicatively relevant translation. Translation transformations are the most widely distributed among other operations at work. The perspective is seen in further investigation of colour names on the different linguistic material and in other Indo-European languages.

Key words: colour names, symbolism, translation operations, translation transformations.
\end{abstract}

Problem-setting and groundings for its urgency. The issues of colour nomination and colour artictic symbolism has been lately in the focus of the research wroks by H.V. Aliyeva [1], N.B. Bakhilina [2], D.N. Borysova [3], A.P. Vasylevych [4], and Yu.V. Normanska [5].

Possible challenges of rendering colour names consist in the absence of the full translation correspondences for particular shades of meaning of certain colour names in the target language on one side, and simultaneously in the acquisition of the symbolic sematic charge in the context of a particular belles-lettres text.

The urgency of the article is conditioned by the necessity of the systematization of translation tactics and techniques, employed in rendering English colour names in Ukrainian artistic translation.

Achromatic colour names, primary, secondary and tertiary colour names functioning in the selected English works of art and their Ukrainian translation correspondences have served as the object of the research. The peculiarities of rendering English colour names in Ukrainian translation in the aspect of the preservatio of their symbolic meaning have formed the subject of the research.

Recent research analysis. The history of the colour names research dates back to the works of such well-known scholars as A. Vezbytska [6], B. Berlin [7] and E. Rosch [8]. Unlike the previous works, dedicated to the issues of fundamentals of visual perception of colour and its proper nomination [6], university and evolution of colour terms [7] and mental codes for colour categories [8].

The novelty of our research consists in the focus upon the translator's artistic interpretation of colour symbolism in translating belles-lettres works from English into Ukrainian.

The objective and tasks. The objective of the research is to perform the comparative translation analysis of achromatic, primary, secondary and tertiary colour nominations, as well as to define the most appropriate translation tactics and techniques of their adequate rendering in Ukriniahn artistic translation in the paradigm of the functional communicative approach. The tasks are as follows:

1) to systematize the existing approaches to the understanding and classification of colour names;

2) to define the distinctive features of colour terms in general;

3) to perform the overall linguistic analysis of English colour nominations on the basis of the long short stories 'Dandelion Wine' by Ray Bradbury [9] and 'The Great Gatsby' by Francis Scott Fitzerald [10];

4) to determine the most appropriate translation tactics and technqiues of rendering colour names in Ukrainian translations by V. Mytrofanova [11] and M. Pichevskyi [12].

The sampling for the research was formed on the basis of the works of art 'Dandelion Wine' by Ray Bradbury and 'The Great Gatsby' by Francis Scott Fitzerald and their Ukrainian translations by V. Mytrofanova and M. Pichevskyi.

The methodology of the research included the methods of sampling, comparative and translation analysis, as well as some elements of the quantitative method.

The findings of the research. Colour names are viewed in the research as linguistic and cultural signs employed not only to nominate and differentiate colours, but also to create artistic symbols.

Colour names are speech products, resulting from colour nomination. They may be represented by different linguistic units (from morphemes to supraphrasal unities), but the common semantic feature is direct or associative connection with the objects of reality as carriers of certain colours. On the basis of the selected Ukrainian translations under analysis there have been singled out the primary and secondary colours and shades of red, black and white, and their peculiarities.

It has been cocluded that colour names' semantics is realized both on linguistic, extralinguistic and cultural levels of belles-lettres texts. Color names are certain codes, symbolizing notions, images or ideas. 
Symbols are especially relevant for translation as they are interwoven with the author's world view. Translators employ translation transformations to preserve stylistic specificity of the source text.

Translation transformations form the basis of all the translation devices, thus allowing the translator to reder the main idea with certain alterations in both semantic and formal aspects.

The sampling of the research consisted of 117 English colour names and 117 Ukrainian translation correspondences.

It's worth remarking that the sampling contained all the eleven lexemes denoting colour in English: 'red', 'orange', 'yellow', 'green', 'blue', 'velvet, 'white', 'grey', 'black', 'pink', and 'brown'.

The most numerous there have proved to be lexeme 'green' (36 examples). Correspondingly there have been singled out 35 examples of the Ukrainian equivalent 'зелений'.

Thus, the distinctive feature of the colour world picture in the long short stories 'Dandelion Wine' by Ray Bradbury and 'The Great Gatsby' by Francis Scott Fitzerald and their Ukrainian translations «Кульбабове вино» by V. Mytrofanova and «Великий Гетсбi» by M. Pichevskyi there proved to be the wide distribution of all the known eleven colour names.

The names of the shades of colour are more numerous in Ukrainian translations than in the source English texts. The translators' personalities and their colour perception and background knowledge also influenced the choice of translation correspondences and possible allusions.

In the structural aspect there are used both simple and composite colour names: 1) composite colour terms with the intensity of colour: 'gold-bright', 'bright yellow', 'dark-green' (Ukrainian translation: «Злотосяйній», «ясна жовтізна», «темно-зелений»); 2) composite colour terms combining stems of different simple colours names: 'brown-yellow' (Ukrainian translation: «коричневожовтий»), 'blue-white' (Ukrainian translation: «голубовато-білі»), 'red velvet' (Ukrainian translation: «червоної оксамитової)), 'red purple' (Ukrainian translation: «червонястий»), 'yellow-dark' (Ukrainian translation: «руда»); 3) composite colour terms combining stems of colour names with the stems of emotive and evaluative connotation, mostly rendered by descriptive translation: 'red-fire, now blue-fire, now white-fire faces' (Ukrainian translation: «обличчя всіх, хто висипав на веранди, запалахкотіли то червоною, то блакитною, то білою барвою»); 4) composite colour terms combining stems of colour names with the stems denoting objects with implied but not explicit colour nomination.

Such lexical units are typical of English and are further subdivided into 5 groups, differentiated by their semantics: 1) the names of natural objects like: 'white moon ice', 'red-fire', 'blue-fire', 'white-fire', 'yellow sunlight'; 2) the names of minerals/metals like: 'lemon glass', 'color sky from iron to blue', 'green gold'; 3) somatisms like: 'red-faced', 'red-brick', 'white-chalk', 'white-capped'; 4) the names of household items or furniture like: 'yellow-toothed piano'; 5) the nominations of food products like: 'black cake'.

Now let's dwell upon the explicit and implied semantics of the colour name 'black'. In English linguistic and mental culture black evokes associations with sadness, depression, grief, distress, despair, evil or malicity like in 'black soul'. In Ukrainian the translation correspondence 'чорний' is also associated with negative meaning as it denoted soot, coal and dirt.

But 'black' is not identical in meanings and associations with 'чорний' as sometimes it rather corresponds to 'темний' as the synonym of 'dark'. This may be illustrated by the example given below.
English text: 'So Tom just sat on the hardwood floor and looked out into dark dark dark, pressing his nose against the screen until the flesh of its tip was molded into small black squares'. Ukrainian text: «Отож Том просто сидів на дерев'яній підлозі веранди й дивився у темну претемну темряву, притиснувщись обличчям до протимоскітної сітки, так що зрештою на кінчико його носа відбилися маленьки темні квадратики».

Nominations of grey colour in Indo-European languages may adhere both to light and dark shades of colour. In transferred meaning 'grey' corresponds to 'plain', 'middle-of-the-road'. In Ukrainian linguistic and mental culture 'gray' is close to 'ageing', 'сивий колір волосся' and at the time may mean 'dull', 'gloomy', thus it may be translated as 'нудний', 'похмурий'. This may be illustrated by the following example: 'And Douglas and Charlie and Tom and all the boys and girls on the block saw the gray glove waving, and dropped: from trees and left skip ropes in white snakes on lawns, to run and sit in the green plush seats, and there was no charge'. The corresponding Ukrainian translation: «I, побачивши, як він заклично махнув рукою в сірій рукавичиі, і Дуглас, i Чарлі, і Том, і всі хлопчиська та дівчатка з цілого кварталу поскочувалися з дерев, покидали на траву білі змійки скакалок, а тоді чимдуж побізли до трамвая й повсідалися на зелених плюшевих сидіннях - i то зовсім безилатно».

'White' often symbolizes 'purity', 'innocence', 'modesty', 'joy', 'prudence'. It is also the colour of wedding in English culture. In Ukrainian all these associations are preserved.

'Red' has two Ukrainian correspondences depending on the context, 'червоний' and 'рудий' .

'Red' may be translated into Ukrainian like 'червоний', 'багряний', 'рум'яний', 'рудий' and еven 'мідний' which corresponds to another English word 'copper'. English text: 'Also red rhubarb, cream of tartar, white sugar, white of eggs, spring water and clover buds with the strength of the good earth in them.' Ukrainian translation: «А ще червоний ревінь, винний камінь, білий цукор, яєчний білок, джерельна вода, пуп'янки конюшини - в них добра сила землі».

'Green' in English symbolizes 'freshness', 'youth', 'harmony', 'health', but at the same time 'lack of experience'. In Ukrainian the translation correspondence 'зелений' also means 'inexperienced', 'young'. Similar in meaning to 'green' is 'verdant', a loan word from French, phonetically and morphologically adapted, widely used to denoted 'an inexperienced person'. English text: 'Soon, in the morning avenues below, two old women would glide their electric Green Machine, waving at all the dogs.' Ukrainian translation: «Невдовзі на ранкові вулиці виїдуть своєю електричною Зеленою машиною дві бабусі, махаючи руками до кожного зустрічного собаки».

'Yellow' has varied meanings and implied associations in English as compared to its Ukrainian translation correspondence «жовтий». Firstly, it denotes the colour of the sun, but it is also employed in the meaning of 'jealous', 'envious', 'cowardly' and 'disloyal'.

English text: 'Yellow squares were cut in the dim morning earth as house lights winked slowly on.' Ukrainian translation: «На оповитій вранішнім серпанком вулиці прорізалися жовті прямокутники - люди вмикали світло в будинках». In this example 'yellow' is used as the synonym of 'lighted'.

In English there are two morphologically similar words with the same colour nomination - 'gold' and 'golden'. Colour name 
'gold' denotes 'made of gold' or 'the best'. Colour name 'golden' denotes 'the colour of gold and its shades'. In transferred meanings 'golden' is more common than 'gold'. In Ukrainian it is translated as 'золотий' or 'блискучо-жовтий'. It corresponds to such Ukrainian adjectives as 'цінний' ('precious', 'valuable'), 'дорогий' ('dear', 'expensive', 'costly') and 'щасливий' ('happy').

English text: 'Even Grandma, repeating and repeating the fine and golden words, even as they were said now in this moment when the flowers were dropped into the press, as they would be repeated every winter for all the white winters in time'. Ukrainian translation: «Навіть бабуся знов і знов повторюватиме ці прекрасні, золоті слова, так само, як їх сказано щойно, коли квіти висипали в прес, так само, як їх буде повторювано кожної зими, кожної білої зими ще багато років по тому».

'Gold-bright', a composite colour term, is translated as «золотосйяний». English text: 'Now discovering this rare timepiece, this clock gold-bright and guaranteed to run threescore and ten, left under a tree and found while wrestling.' Ukrainian translation: «Тільки тепер, зчепившись із Томом, знайшов отут, під деревом, цей рідкісний хронометр, цей злотосяйний годинник з гарантією безупинного ходу років на сімдесят».

'Blue' has strong associations with 'the colour of the sky and water', but it may also mean 'depressed' or 'depressing', 'gloomy'. In Ukrainian it is translated as «блакитний». Such English colour terms as 'azure' and 'turquoise' correspond to Ukrainian «азуровий» and «бірюзовий». English text: 'She showed him the blue envelope, which she now sealed and pressed flat'. Ukrainian translation: «Вона показала блакитний конверт, щойно заклеєний і пригладжений рукою».

'Pink' is associated with 'the colour of roses' and corresponds to the Ukrainian colour name 'рожевий'. English text: 'They saw the pink ash swinging gently to and fro.' Ukrainian translation: «Подруги побачили рожевий вогник, що помалу хилитався сюди-туди».

The conclusions and perspective. According to the results of the analysis of the peculiarities of rendering English colour names in Ukrainian translation of belles-lettres texts aimed at defining dominant translation tactics and operations, the following conclusions have been drawn.

The most recurrent translation tactics there have proved to be the tactic of relevant information rendering, the tactic of correct information presentation, and the tactic of linguistic and cultural adaptation.

As far as translation operations are concerned, the most recurrent there are search of translation equivalent $-45 \%$, contextual replacement $-35 \%$, semantic development $-15 \%$ and addition $-5 \%$.

It has been proved that the semantics of colour names is realized and respectively rendered in belles-lettres texts on linguistic, extralinguistic and cultural levels. The symbolic meaning is often made explicit and the transferred meaning is mostly rendered. Due to the adequate rendering of all the stylistic devices employed the pragmatics and general tonality of the works of art is preserved.

The perspective is seen in further investigation of colour names on the different linguistic material and in other Indo-European languages.

\section{References:}

1. Алиева Г.В. Обозначение цвета и универсалии зрительного восприятия. Язык. Культура. Познание. Москва : Русские словари, 2001. С. 231-290.

2. Бахилина Н.Б. История цветообозначений. Москва : Наука, 1975. $224 \mathrm{c}$.
3. Борисова Д.Н. К проблеме выбора термина для названия формцветообозначения в языке. Вестник Челябинского государственного университета. Челябинск, 2008. Вып. 23. № 21(122). С. 32-37.

4. Василевич А.П. Языковая картина мира цвета. Методы исследования и прикладные аспекты : автореф. дис. ... д. филол. наук. Москва, 2003. 95 с.

5. Норманская Ю.В. Историко-типологический анализ цветообозначений в древних индоевропейских языках : автореф. дис. ... канд. филол. наук. Москва, 2002. 22 с.

6. Вежбицкая А. Обозначение цвета и универсалии зрительного восприятия. Язык. Культура. Познание. Москва : Русские словари, 1997. С. 231-290.

7. Berlin B. Basic Color Terms, their Universality and Evolution. Los Angeles : Berkeley, 1969. 178 p.

8. Rosch E. The nature of mental codes for colour categories. Journal of experimental psychology: Human perception and performance. 1975. Vol. 1. P. 303-332.

9. Bradbury R. Dandelion Wine. Bantam Doubleday Dell Publishing Group, 1987. 256 p.

10. Fitzerald F. S. The Great Gatsby. Macmillan Education, 2008. 88 p.

11. Бредбері Р. Кульбабове вино / пер. В. Митрофанова. Київ, 2015. $432 \mathrm{c}$.

12. Фіцджеральд Ф.С. Великий Гетсбі / пер. М. Пінчевського. Київ, 2016. $200 \mathrm{c}$.

\section{Серебрякова В. Особливості відтворення} англійських колоронімів у перекладі українською мовою

Анотація. Статтю присвячено опису колоронімів у функціональному та перекладацькому аспекті, зокрема в аспекті їх адекватного відтворення у перекладі українською англомовних художніх творів. Колороніми досліджуються як лінгвістичні одиниці, що визначаються високим ступенем адаптивності та варіативності залежно від досвіду та картини світу автора. У роботі розглядаються питання адекватного відтворення імпліцитної семантики колоронімів у художньому тексті. Номінації колору також аналізуються як культурні символи, носії певної ментальності та експресивності. Тема дослідження $є$ актуальною 3 позиції функціонально-комунікативному підходу до перекладу. У роботі досліджуються різні типи англійських колоронімів та особливості їх відтворення у перекладі українською мовою. Дослідження провадилось на матеріалі оповідань «Кульбабове вино» Рея Бредбері та «Великий Гетсбі» Френсіса Скотта Фіцджеральда. Колороніми реалізуються в художніх творах на лінгвістичному, екстралінгвістичному та культурному рівнях. Було підтверджено наявність символічного значення колоронімів у художніх текстах. Наявність асоціативного зв'язку 3 метальністю та світоглядом автора засвідчує релевантність символів для художнього перекладу. Було зроблено висновок про важливість адекватного відтворення колоронімів для якості перекладу. У процесі дослідження було проаналізовано перекладацькі тактики та операції. Було зроблено висновок, що задля збереження стилістичної специфіки вихідного твору, зокрема у частині відтворення колоронімів, перекладачі використовують влучні перекладацькі операції відповідно до обраної стратегії комунікативно-рівноцінного перекладу. Серед перекладацьких операцій значне місце посідають перекладацькі трансформації. Перспектива вбачається в подальшому дослідженні колоронімів на іншому мовному матеріалі та в інших індоєвропейських мовах із акцентом на їх адекватному відтворенні.

Ключові слова: колороніми, символізм, перекладацькі операції, перекладацькі трансформації. 